\title{
Loess deposition in Asia: its initiation and development before and during the Quaternary
}

1 Geological Institute, Russian Academy of Sciences, Pyzhevsky, 7, 119017, Moscow, Russia. E-mail: dodonov@ginras.ru

2 Laboratory for Earth Surface Processes, Department of Geography, Peking University, Beijing 100871, China.E-mail: lpzhou@pku.edu.cn

Dust is important in the Earth environment system. However, the role of dust in climate change remains largely unknown. A better understanding of the temporal and spatial variability of the dust accumulation in Asia forms an important step towards establishing the link between dust deposition and climate change. Here, a summary is given for the timing of the onset and expansion of loess deposition in Asia beginning in the early Miocene. Recent progress on some aspects of loess chronology and palaeoenvironmental reconstruction is also reviewed.

\section{Introduction}

Loess is a very characteristic sedimentary unit in Asia, providing enormous archives for the geological history of the Quaternary. Loess areas of Asia are highly populated regions with intensively developed agriculture, large towns, industrial and hydrological constructions.

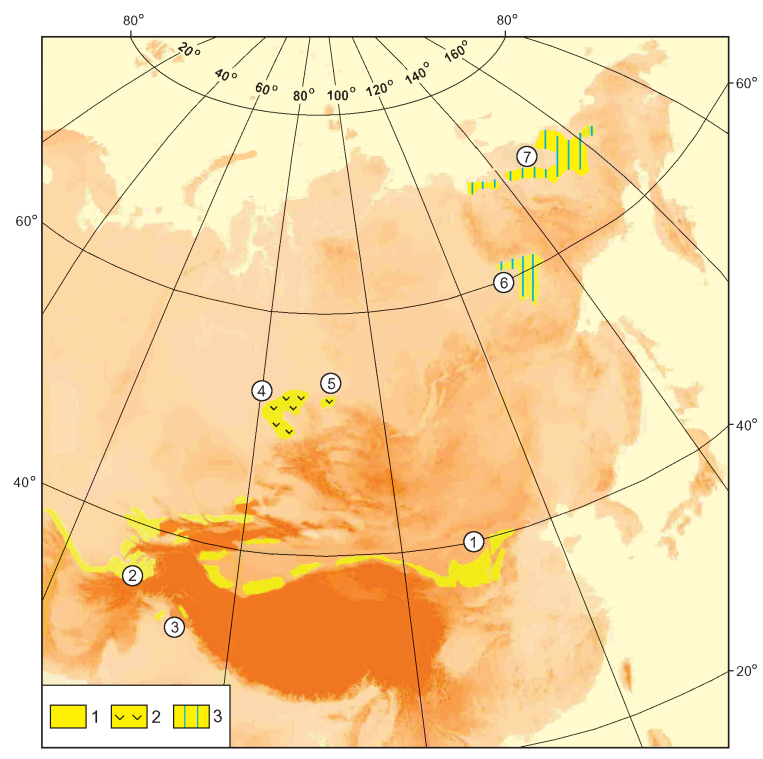

Figure 1 Schematic map showing distribution of loess and loesslike deposits in Asia.

1-loess of arid zone; 2-loess and loesslike silt in periglacial zone; 3-loess and loesslike silt with inclusion of ice in subarctic zone. Regions of loess and loesslike silts referred in the paper (figures in circles): 1-Loess Plateau of Northern China; 2-Central Asia, Tadjikistan; 3-Central Asia, Kashmir Valley, Peshavar Basin, Potvar Palteau; 4-Ob' Plateau of south Western Sibereia; 5Kurtak region in the Enisei Valley of south Eastern Siberia; 6Central Yakutiya; 7-Northern Yakutiya.
Loess studies of Asia are associated with famous names such as von Richthofen, Obruchev, Pavlov, Liu Tungsheng, Kriger and others (Smalley et al., 2001), who pioneered fundamental studies of loess origin, lithologic characteristics, and deposition processes. Many properties of loess, such as high permeability, loose structure, erosive capability, collapsibility, suffosion, landsliding, and underflooding pose huge challenges to the people living in loess regions.

As a great subcontinent, Asia is characterized by extremely continental climatic conditions in the central part, as well as significant regional changes from the north to the south. These features define a considerable diversity of loess sequences from the arid zone in Central Asia and North China to the periglacial zone in South Siberia, and subarctic frozen loess zone in Central and Northern Yakutiya (Figure 1).

Intensive investigations have been undertaken in order to understand the paleoenvironmental significance of the loess formation in different parts of Asia. Nevertheless, some of the fundamental scientific questions remain outstanding: When did loess accumulation start in Asia? What were the controlling factors for the initiation of loess accumulation? Where did the silty materials come from? And what was the relationship between dust deposition and climate in the past? Here we provide an overview of some of the recent development in loess research with particular reference to the pattern of initial loess deposition across Asia.

\section{The onset and expansion of aeolian deposition in different parts of Asia}

Northern China and Central Asia are characterized by the most complete known loess strata, embracing Quaternary time back to ca. 2.6 Ma (Liu et al., 1985; Kukla and An, 1989; Rutter et al., 1991; Ding et al., 2002; Dodonov, 1991, 2002). Due to the lack of any features that are characteristic of cryogenic processes, loess here is considered as "warm-climate" loess with dominant sources from desert or dryland (Smalley et al., 2001). With the intensive investigation of the Red Clay at Xian, Xifeng, Lingtai and Jiaxian of Chinese Loess Plateau, the start of aeolian deposition in Asia was extended to 7-8 Ma (Liu et al., 1991; Sun et al., 1998; Ding et al., 1999; Qiang et al., 2001). New data from the southwestern part of the Loess Plateau point to even earlier aeolian deposition in northern China (Figure 2), extending back to the LowerMiddle Miocene (Guo et al., 2002; Qiao et al., 2006). An important implication of this new finding is that desert dust sources were developed since the Miocene and arid conditions, dust deflation and aeolian accumulation became a characteristic of the environment from that time. Another implication is concerned with the wind systems responsible for the transport of the dust materials. In China, this would be related to the development of monsoonal system (e.g., An, 2000; Guo et al., 2002).

During the Pliocene and Pleistocene, neotectonic uplift of the Tibetan Plateau, Himalayas and Tian Shan mountains (Liu and Ding, 1984; Burbank and Raynolds, 1984; Chadiya, 1986; Li et al., 1995; Dodonov, 2002) caused more isolation of internal parts of Central Asia and stimulated desiccation of the regional climate. It is conceiv- 


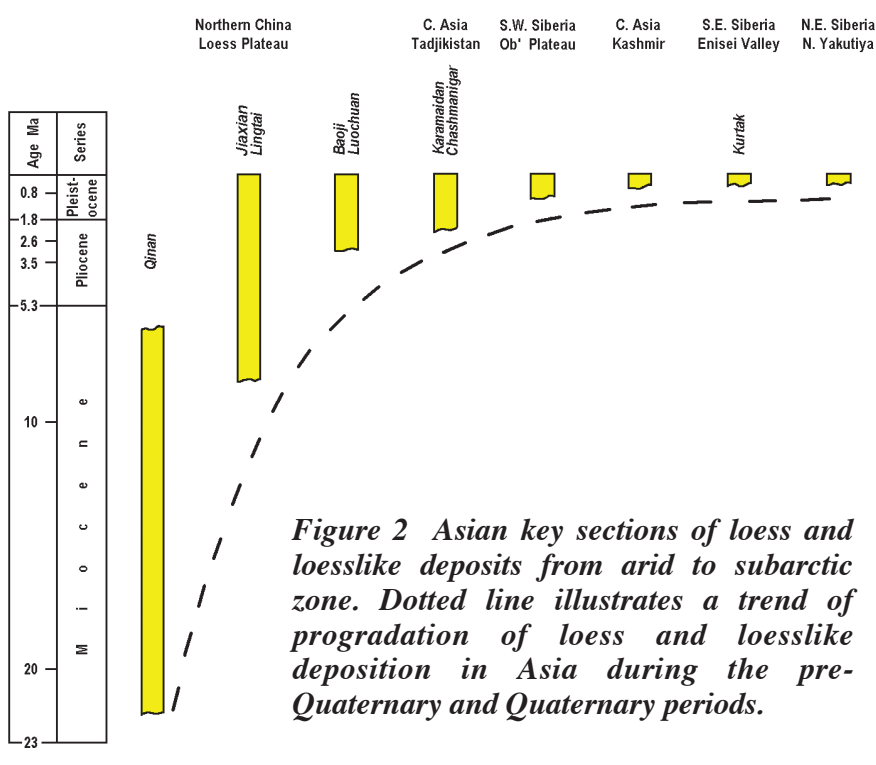

able that such a change in landform and climate has formed the background for the large-scale dust generation and deposition in Asia. The distribution of Miocene aeolian deposits is mostly confined to the west of the Liupan Mountain probably constrained by geomorphic conditions. The subsequent Pliocene aeolian deposits were spread into wider areas in the Loess Plateau but still mostly confined to areas which had favourable conditions for dust trapping. The cause for the expansion has yet to be established. In Central Asia, the Early Pleistocene was a crucial time when loess became one of the dominat types of sedimentation in Northern China and Tadjikistan. Further enlargement of the arid area and development of more favorable conditions for loess aggradation in the Middle and Late Pleistocene widened loess distribution, resulting in spatial expansion of loess provinces to the Kashmir Valley, Peshavar Basin and Potvar Plateau where loess sequences are dated from the Middle to Late Pleistocene (Bronger et al., 1987; Singhvi et al., 1987; Rendell, 1988). In south Western Siberia, loess accumulation began in the early Middle Pleistocene (Zykina, 1999). This area belongs to the periglacial zone where loess is considered as "cold-climate" loess with many traces of cryogenic effects (Smalley, 1995; Smalley et al., 2001). Another super-cold subarctic area, situated further to the north, became more arid at the end of Middle Pleistocene and in the Late Pleistocene (Figure 2). In Northern Siberia, desiccation and freezing processes during the Last Glacial Maximum led to widespread production of fine-grained sediments as loess or loesslike silt with inclusion of thick syngenetic polygonal ice wedges sometimes reaching up to $70-80 \%$ of the sediment volume. Because of their unusually high ice content, these deposits are known as the 'loess-ice complex', 'ice complex', or 'edoma' (Tomirdiaro, 1980; Kaplina and Lozhkin, 1984). 'Edoma' sediments or frozen loess (loesslike silt) is typical of the Yana-Indigirka and Kolyma lowlands in north Eastern Siberia. An aeolian origin has been hypothesised as an alternative to a fluvial and polygenetic origin (Tomirdiaro, 1980). On the Quaternary map of Russia (2001), the areas covered by ice-rich loess (loess containing ice) are shown in the Yana-Indigirka Plain of Northern Yakutiya. In Central Yakutiya, loesslike silt mantles form a blanket on river terraces and upland surface of irregular topography. The aeolian origin of this silt was long disputed but has gained strong support in later studies (e.g., Péwé and Journaux, 1983).

\section{Chronological framework}

One of the key issues in loess study and paleogeographic reconstruction is the stratigraphic correlation between different zones. This has been achieved by numerical dating and by means of long-term climate variability recorded in the loess sequences. Paleoclimatic fluc- tuations are manifested in loess strata as the alternation of soil and loess horizons, which serve as key markers for detailed subdivision and correlation (Derbyshire et al., 1995). Paleomagnetic measurements, tied to the Geomagnetic Polarity Time Scale provide valuable geochronological controls. The Gauss/Matuyama reversal ( 2.6 Ma) falls near the lithological transition between the Red Clay strata and overlying Wucheng Loess at the level of loess horizon L33 in most of the Chinese sections, for example Xian, Xifeng, Lingtai and Jiaxian (Liu et al., 1991; Sun et al., 1998; Ding et al., 1999, Qiang et al., 2001). In Central Asia, in Tadjikistan, the Gauss/Matuyama boundary was determined at the base of loess stratum in the most complete loess section of Karamaidan (Dodonov, 2002).

Another chronostratigraphic marker, the Matuyama/Brunhes (M/B) reversal ( 0.78 Ma), is also very useful for correlation of the Middle and Upper Pleistocene loess series. In the Loess Plateau, the $\mathrm{M} / \mathrm{B}$ reversal is located between paleosols S8 and S7 (Heller and Liu, 1984). In Tadjikistan, the M/B reversal is located in the loess horizon between tenth and ninth pedocomlexes (PC), or at the base of PC9 (Dodonov and Pen'kov, 1977; Dodonov, 1991; Forster and Heller, 1994). As in Tadjikistan, in the Ob' Plateau of south Western Siberia, nine major pedocomplexes and loess units are present in loess deposits above the M/B boundary (Zykina, 1999). It should be noted that the measured positions of the $\mathrm{M} / \mathrm{B}$ and other geomagnetic reversals in loess may be variably affected by the lock-in effect of the magnetic remanence (e.g., Zhou and Shackleton, 1999) although there is still difference in the understanding of the disparity in $\mathrm{M} / \mathrm{B}$ boundary between the loess and marine geomagnetic records (e.g., Spassov et al., 2003; Wang et al., 2006). The varying displacement could introduce significant uncertainty in loess stratigraphical correlation. The uncertainty may become strikingly larger when loess records are correlated with marine and ice isotope records.

For the youngest parts of loess sequences, luminiscence dating has become a major tool in establishing chronology for the Late Pleistocene (Murray and Wintle, 2000; Roberts and Wintle, 2001; Zhou and Shackleton, 2001; Stevens et al., 2006; Lai et al., 2007). The Last Interglacial soil horizon, S1 in Chinese sections, PC1 in Tadjikistan and Kurtak paleosol in south Eastern Siberia is dated in the range of 130-70 ka, corresponding to the entire MIS 5 (Liu et al., 1985; Zhou et al., 1995; Frechen and Dodonov, 1998; Frechen et al., 2005). This serves as an important time marker in loess stratigrphy. Recent optically stimulated luminescence studies show significant age underestimation for some of the late Pleistocene loess from China (e.g., Qin and Zhou, 2007; Buylaert et al., 2008). However, the precise extent of uncertainty in chronology may vary for different loess regions and has been hard to establish due to the lack of other dating materials. This requires further investigation.

\section{Diversity in magnetic susceptibility records}

Variations in magnetic susceptibility of loess-paleosol sequences have been shown to track the development of the pedogenetic processes that depend on paleoclimatic conditions during the Quaternary (Zhou et al., 1990; Heller et al., 1991; Maher and Thompson, 1991; Forster and Heller, 1994; Shackleton et al., 1995, An, 2000; Ding et al., 2002). It has been one of the most commonly used tools for stratigraphical correlation as well as for paleoenvironmental reconstruction. The magnetic susceptibility of loess and paleosols from northern China and Tadjikistan show remarkable coherence with the oxygen isotope record of the deep sea cores with higher magnetic susceptibility values in paleosols and lower values in loess due to pedogenic enhancement during relatively wetter and warmer intervals (Forster and Heller, 1994; Shackleton et al., 1995; Ding et al., 2002). Note, however, the two regions are under different climate regimes, i.e. being monsoonal and non-monsoonal. The Siberian loess-paleosol succession has completely opposite magnetic susceptibility pattern. Here a gradual magnetic mineral depletion occurs during soil formation which, when coupled with more intense wind activity during the cold intervals (leading to accumulation of greater 
quantities of larger ferromagnetic grains) gives higher magnetic susceptibility values in the loess (Chlachula, 1999; Zhu et al., 2003). The paleoclimatic interpretation of magnetic susceptibility of pre-Quaternary loess or loesslike deposits is more complicated and should be made with caution (Ding et al., 1998; Liu et al., 2003).

\section{Sedimentation rate}

The intensity of the aeolian dust sedimentation has generally increased during the Quaternary (Dodonov, 2002). For example, based on magnetostratigraphy, an average dust accumulation rate of approximately $1.67 \mathrm{~cm} / \mathrm{kyr}$ was obtained for the Qinan Miocene subaerial section in southwestern Loess Plateau (Guo et al., 2002). The Red Clay (Red-Earth) formation, characterized mostly by aeolian derived particle size composition especially for its Pliocene middle and upper parts, accumulated at an average rate of $1.5-3.5 \mathrm{~cm} / \mathrm{kyr}$ (Guo et al., 2001). The average rate for loess sedimentation in South Tajikistan was in the range of $6 \mathrm{~cm} / \mathrm{kyr}$ in the Lower Pleistocene, increased during the Middle Pleistocene and attained rates of 40-50 $\mathrm{cm} / \mathrm{kyr}$ to the Late Pleistocene during the Last Glacial Maximum (Dodonov, 2006). The average loess accumulation in China, at Luochuan section, changes from $4.5 \mathrm{~cm} / \mathrm{kyr}$ below the Jaramillo Subchron $(1.07-0.99 \mathrm{Ma})$ to $7.5-10 \mathrm{~cm} / \mathrm{kyr}$ in the upper part of the sections (Heller and Liu, 1984). Thus, it appears that similar, proportional changes of loess sedimentation rates have occurred in different loess provinces. This suggests that the general pattern in the development of aeolian processes across different regions of Asia might have been determined by progressive, continent-wide paleoclimatic changes.

\section{Definition of ancient aeolian deposits}

At the moment, the aeolian deposits from northern China have been given different identities such as loess, red clay and Miocene loess. In the context of identifying early loess deposition, Pécsi's opinion should be mentioned. He suggested that "Wucheng loess" can not be considered as typical loess due to significant difference in lithological properties in comparison with younger Lishi loess (Pécsi, 1987). Whether the term loess can be used for ancient Miocene and Pliocene parts of the Chinese sections, e.g., at Qinan, Lingtai, Xifeng and others is still a matter for discussion because the strata contain thin dispersed sediments that have lost some of the features characteristic of typical loess. A clarification of the nomenclature may therefore help to understand the processes and environments during the loess formation.

\section{Concluding remarks}

In summary, the distribution, characteristics and age of loess or loesslike silts since the Miocene allows reconstruction of the general trends of environmental changes and the loess progradation in Asia from the most arid areas in the central parts to the temperate and high latitudes of the subcontinent (Figure 2). The initial accumulation of loess in Asia is associated with the neotectonic uplift of the main mountain systems in Central Asia which caused significant aridification of this region. Quaternary glaciations further increased desiccation in the different zones from the south to the north. The characteristic lithological features of loess and loesslike deposits in the different zones thus reflect the specific environmental conditions that were developed prior to and during the Quaternary. As Asian loess deposits occur under both monsoonal and non-monsoonal climates, loess sequences in Asia therefore can serve as long-term records of different climate regimes.

\section{Acknowledgements}

We thank Brad Pillans, Ian Smalley and an anonymous reviewer for critical reading of manuscript and constructive suggestions. The work was supported by NSFC (No 40773002 and No 49925307) and RFBR (Project No 06-05-64049).

\section{References}

An Z.S., 2000, The history and variability of the East Asian paleomonsoon climate: Quaternary Science Reviews, 19, pp. 171-187.

Bronger A., Pant R.K., and Singhvi A.K., 1987, Micromorphology, mineralogy, genesis and dating of loess-paleosol sequences and their applicaton to Pleistocene chronostratigraphy and paleoclimate: A comparison between southeast Central Europe and the Kashmir Valley/Central Asia. Aspects of loess research. Beijing: China Ocean Press, pp. 121-129.

Burbank D.W. and Raynolds R.G.H., 1984, Sequential late Cenozoic structural disruption of the northern Himalayan foredeep: Nature, 311, pp. $114-118$.

Buylaert J.P., Murray A.S., Vandenberghe D., Vriend M., De Corte F., Van den Haute P., 2008, Optical dating of Chinese loess using sand-sized quartz: Establishing a time frame for Late Pleistocene climate changes in the western part of the Chinese Loess Plateau: Quaternary Geochronology, 3, pp. 99-113.

Chadiya O.K., 1986, Morphostucture and newest tectogenesis of Tian Shan. Frunze. ILIM. 314 pp. (In Russian).

Chlachula J., 1999, Loess-paleosol stratigraphy in the Yenisey basin, Southern Siberia. Eds. J.Chlachula, R.A.Kemp, and J.Tyraček, Quaternary of Siberia: Journal of Geological Sciences, 23. Prague, pp. 55-70.

Derbyshire E., Kemp R., and Meng X.M., 1995, Variations in loess and paleosol properties as indicators of paleoclimatic gradients across the Loess Plateau of north China: Quaternary Science Reviews, 14, pp. 681-697.

Ding Z.L., Sun J.M., Liu T.S., Zhu R.X., Yang S.L., Guo B., 1998, Windblown origin of the Pliocene red clay formation in the central Loess Plateau, China: Earth and Planetary Science Letters, 161, pp. 135-143.

Ding Z.L., Xiong S.F., Sun J.M., Yang S.L., Gu Z.Y., and Liu T.S., 1999, Pedostratigraphy and paleomagnetism of a $\sim 7.0$ Ma aeolian loess-red clay sequence at Lingtai, Loess Plateau, north-central China and the implications for paleomonsoon evolution: Palaeogeography, Palaeoclimatology, Palaeoecology, 152, pp. 49-66.

Ding Z.L., Ranov V., Yang S.L., Finaev A., Han J.M., Wang G.A., 2002, The loess record in southern Tajikistan and correlation with Chinese loess: Earth and Planetary Science Letters, 200, pp. 387-400.

Dodonov A.E., 1991, Loess of Central Asia: Geol. Rundsch. 24, pp. 185-194.

Dodonov A.E., 2002, Quaternary of Middle Asia. Stratigraphy, correlation, paleogeography. Moscow. GEOS. 250 pp. (In Russian).

Dodonov A.E., 2006, Loess Records. Central Asia. Encyclopedia of Quaternary Science. Elsevier, Vol. 2, pp. 1418-1429.

Dodonov A.E. and Pen'kov A.V., 1977, Some data on the stratigraphy of the watershed loesses in Tadjik Depression: Bulletin of the Commission on the Quaternary Research, 47, pp. 67-76. (In Russian).

Forster Th. and Heller F., 1994, Loess deposits from the Tadjik depression (Central Asia): Magnetic properties and paleoclimate: Earth and Planetary Science Letters, 128, pp. 501-512.

Frechen M. and Dodonov A.E., 1998, Loess chronology of the Middle and Upper Pleistocene in Tadjikistan:. Geol. Rundsch. 87, pp. 2-20.

Frechen M., Zander A., Zykina V., and Boenigk W., 2005, The loess records from the section at Kurtak in Middle Siberia: Palaeogeography, Palaeoclimatology, Palaeoecology, 228, pp. 228-244.

Guo Z.T., Peng S.Z., Hao Q.Z., Biscaye P.E., and Liu T.S., 2001, Origin of the Miocene-Pliocene Red-Earth Formation at Xifeng in Northern China and implications for paleoenvironments: Palaeogeography, Palaeoclimatology, Palaeoecology, 170, pp. 11-26.

Guo Z.T., Ruddiman W.F., Hao Q.Z., Wu H.B., Qiao Y.S., Zhu R.X., Peng S.Z., Wei J.J., Yuan B.Y., and Liu T.S., 2002, Onset of Asian desertification by 22Myr ago inferred from loess deposits in China: Nature, 416, pp 159-163.

Heller F., Liu T., 1984, Magnetism of Chinese loess deposits: Geophys. J. R. astr. Soc. 77, pp. 125-141.

Heller F., Liu X., Liu T., and Xu T., 1991, Magnetic susceptibility of loess in China: Earth and Planetary Science Letters, 103, pp. 301-310.

Kaplina T.N. and Lozhkin A.V., 1984, Age and history of accumulation of 'ice complex' of the maritime lowlands of Yakutyiya, in: Ed. A.A.Velichko, 
Late Quaternary environments in the Soviet Union: Longman. London, pp. 147-151.

Kukla G. and An Z., 1989, Loess stratigraphy in Central China: Palaeogeography, Palaeoclimatology, Palaeoecology, 72, pp. 203-225.

Lai Z.P., Wintle A.G., Thomas D.S.G., 2007, Rates of dust deposition between 50 $\mathrm{ka}$ and $20 \mathrm{ka}$ revealed by OSL dating at Yuanbao on the Chinese Loess Plateau: Palaeogeography, Palaeoclimatology, Palaeoecology, 248, pp. $431-439$.

Li J. et al., 1995, Uplift of Qinghai-Xizang (Tibet) Plateau and global change: Lanzhou University Press. 207 pp.

Liu T.S. and Ding M., 1984, The characteristics and evolution of the palaeoenvironment of China since the Late Tertiary, in: The evolution of the East Asian environment, Proc. Int. Conf. Vol. 1: Geology and Palaeoclimatology. Hong Kong, pp. 11-40.

Liu T.S. et al., 1985, Loess and the environment: China Ocean Press, Beijng. 251 pp.

Liu X., Liu T.S., Shaw J., Heller F., Xu T., and Yuan B., 1991, Paleomagnetic and paleoclimatic studies of Chinese loess, in: Ed. Liu T.S., Loess, environment and global change: Science Press, Beijing, pp. 61-81.

Liu X.M., Rolph T., An Z.S., Hesse P., 2003, Paleoclimatic significance of magnetic properties on the Red Clay underlying the loess and paleosols in China: Palaeogeography, Palaeoclimatology, Palaeoecology, 199, pp. 153-166.

Maher B.A., Thompson R., 1991, Mineral magnetic record of the Chinese loess and paleosols: Geology 19, pp. 3-6.

Murray A.S., Wintle A.G., 2000, Luminescence dating of quartz using an improved single-aliquot regenerative dose protocol: Radiation Measurements, 2000, 32, pp 57-73.

Pécsi M., 1987, International Loess Symposium in China, Xian, Shaanxi Province, October 15-16, 1985: GeoJornal, 14, 4, pp. 435-445.

Péwé T.L. and Journaux A., 1983, Origin and character of loesslike silt in unglaciated South-Central Yakutia, Siberia, U.S.S.R. Geological Survey professional paper, 1262. US Government Printing Office, Washington. 46 pp.

Qiang X.K., Li Z.X., Powell C.McA, Zheng H.B., 2001, Magnetostratigraphic record of the Late Miocene onset of the East Asian monsoon, and Pliocene uplift of northern Tibet: Earth and Planetary Science Letters, 187, pp. 83-93.

Qiao Y., Guo Z., Hao Q., Yin Q., Yuan B., and Liu T., 2006, Grain-size features of a Miocene loess-soil sequence at Qinan: Implications on its origin: Science in China. Ser. D, Earth Science, 49, 7, pp. 731-738.

Qin J.T. and Zhou L.P., 2007, Optically Stimulated Luminescence Dating of Upper Part of a Thick Loess Section at Caoxian near the Northern Desert of China: Quaternary Sciences, 27, pp.546-552. (Chinese with English abstract).

Quaternary map of Russia, 1:5 000 000, 2001, Eds. I.I.Krasnov, B.A.Borisov, and E.A.Minina. All Russian Geological Research Institute (VSEGEI). St. Petersburg.

Rendell H., 1988, Environmental changes during the Pleistocene in the Potwar Plateau and Peshawar Basin, Northern Pakistan. Paleoclimatic and paleoenvironmental changes in Asia during the last 4 million years: New Delhi, Indian National Sci. Acad., pp. 58-66.

Roberts H.M., Wintle A.G., 2001, Equivalent dose determinations for polymineralic fine-grains using the SAR protocol: Application to a Holocene sequence of the Chinese Loess Plateau: Quaternary Science Reviews, 2001, 20, pp. 859-863.

Rutter N., Ding Z., and Liu T., 1991, Comparison of isotope stages 1-61 with the Baoji-type pedostratigraphic section of north-central China: Canadian Journal of Earth Sci., 28, pp. 985-990.

Shackleton N.J., An Z., Dodonov A.E., Gavin J., Kukla G.J., Ranov V.A., and Zhou L.P., 1995, Accumulation rate of loess in Tadjikistan and China: Relationship with global ice volume cycles: Quaternary Proceedings, 4, pp. 1-6.

Singhvi A.K., Bronger A., Pant R.K., and Sauer W., 1987, Thermoluminescence dating and its implication for the chronostratigraphy of loess-paleosol sequences in the Kashmir Valley (India): Chemical Geology, 65, pp. 45-56.

Smalley I., 1995, Making the material: The formation of silt sized primary mineral particles for loess deposits: Quaternary Science Reviews, 14, pp. 645-651.

Smalley I.J., Jefferson I.F., Dijkstra T.A., Derbyshire E., 2001, Some major events in the development of the scientific study of loess: Earth-Science Reviews, 54, pp. 5-18.

Spassov, S., Heller, F., Evans, M.E.,Yue, L.P., von Dobeneck, T., 2003. A lock-in model for the complex Matuyama/Brunhes boundary record of the loess/paleosol sequence at Lingtai (Central Chinese Loess Plateau): Geophys. J. Int., 155 , pp. 350-366.

Stevens T., Armitage S.J., Lu H.Y., and Thomas, D.S.G., 2006, Sedimentation and diagenesis of Chinese loess: Implications for the preservation of continuous, high resolution climate records: Geology, 34, pp. 849-852.

Sun, D.H., Shaw, J., An, Z.S., Cheng, M., Yue, L.P., 1998, Magnetostratigraphy and paleoclimatic interpretation of a continuous 7.2 Ma Late Cenozoic eolian sediments from the Chinese Loess Plateau: Geophys. Res. Lett. 25, pp. 85-88.
Tomirdiaro S.V., 1980, Loess-ice formation of Eastern Siberia during the Late Pleistocene and Holocene: Moscow, Nauka, 184 pp. (In Russian).

Wang X.S., Yang Z.Y., Løvlie R., Sun Z.M., Pei J.L., 2006. A magnetostratigraphic reassessment of correlation between Chinese loess and marine oxygen isotope records over the last 1.1 Ma: Phys.Earth Planet. Int., 159, pp. 109-117.

Zhou L.P., Dodonov A.E., and Shackleton N.J., 1995, Thermoluminescence dating of the Orkutsay loess section in Tashkent Region, Uzbekistan, Central Asia: Quatenary Science Reviews, 14, pp. 721-730.

Zhou L.P., Oldfield F., Wintle A.G., Robinson S.G. and Wand J.T., 1990, Partly pedogenetic origin of magnetic variations in Chinese loess: Nature, 346, pp. 737-739.

Zhou L.P. and Shackleton N.J., 1999, Misleading positions of geomagnetic reversal boundaries in Eurasia loess and implications for correlaton between continental and marine sedimentary sequences: Earth and Planetary Science Letters, 168 , pp. $117-130$.

Zhou L.P. and Shackleton N.J., 2001, Photon stimulated luminescence of quartz from loess and effects of sensitivity change on palaeodose determination: Quaternary Science Reviews, 20, pp. 853-857.

Zhu R.X., Matasova G., Kazansky A., Zykina V., Sun J.M., 2003, Rock magnetic record of the last glacial-interglacial cycle from the Kurtak loess section, southern Siberia: Geophysical Journal International, 152, pp. 335-343

Zykina V.S., 1999, Pleistocene pedogenesis and climatic history of Western Siberia. Eds. J.Chlachula, R.A.Kemp, and J.Tyraček, Quaternary of Siberia: Journal of Geological Sciences, 23. Prague, pp. 49-54.

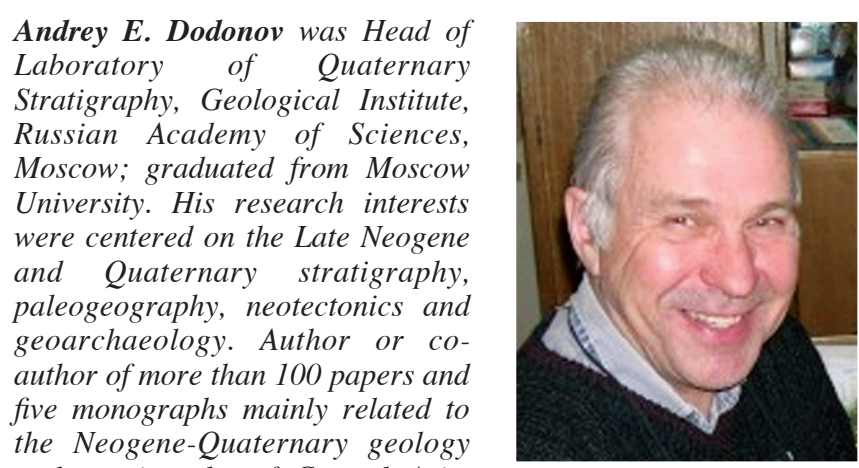
the Neogene-Quaternary geology and stratigraphy of Central Asia, Eastern Mediterranean and South Russia. He was Secretary of the INQUA Loess Commission.

\begin{abstract}
Liping Zhou is mainly engaged with research in luminescence dating and magnetism of loess deposits in northern mid-latitudes, and teaches at Peking University. He studied geomorphology and Quaternary geology at Peking University and holds a PhD degree from University of Cambridge. His current research interests include geochronology of long-term environmental changes and land-ocean correlation; history of human impact in northern China; isotope geochemistry of modern and ancient dust deposits; applications of cosmogenic nuclides in chronostratigraphy and Quaternary landform evolution. He serves as Secretary of Stratigraphy and Chronology Commission, INQUA.
\end{abstract}

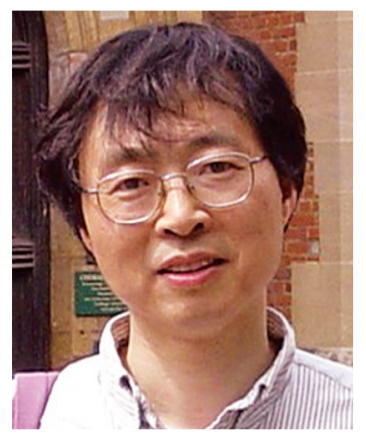

Editor's note: Since completing this article Dr Andrey Dodonov died following a heart attack on 7 May. He will be greatly missed by his colleagues. 